\title{
Peranan Permainan Tradisional Dalam Mengembangkan Kemampuan Matematika Anak Usia Sekolah Dasar
}

\author{
The Role of Traditional Games In Developing The Mathematical Ability of Age Of Basic \\ Schools
}

\author{
Nurdiana Siregar ${ }^{1} *$, Wiwik Lestari \\ ${ }^{1}$ Prodi Pendidikan Guru Sekolah Dasar, Universitas Nahdlatul Ulama Sumatera Utara. Jalan H. A. \\ Manaf Lubis No.2 Medan, 20215 \\ * Korespondensi Penulis. E-mail: nurdiana884@yahoo.co.id, Telp: +6281265509984
}

Keywords:

Permainan tradisional Kemampuan matematika

\begin{abstract}
Abstrak
Penelitian ini bertujuan untuk 1) mendeskripsikan jenis-jenis permainan tradisional yang berkaitan dengan kegiatan matematika, 2) menelaah peranan permainan tradisional anak dalam melatih kemampuan berhitung, dan 3) menelaah peranan permainan tradisional anak dalam mengenalkan bentuk bangun datar pada anak di Desa Hamparan Perak. Penelitian ini menggunakan pendekatan kualitatif yaitu data yang diperoleh dianalisis secara deskriptif. Subjek penenlitian sebanyak 40 orang yang berada pada usia Sekolah dasar (SD) yang berdomisili di Desa Hamparan Perak. Teknik pengumpulan data yaitu observasi, wawancara, dan dokumentasi. Hasil penelitian yaitu : 1) jenis permainan tradisional yang mengandung unsur matematika yaitu permainan tradisional engklek, kelereng, dan batu serimbang, 2) permainan tradisional melatih anak untuk membilang, mengenal angka, membandingkan, dan kemampuan berhitung seperti penjumlahan dan perkalian, 3) permainan tradisional membuat anak menggambar garis, persegi, persegi panjang, trapesium, segitiga, dan lingkaran.

Copyright (C) 2018 Universitas Mercu Buana Yogyakarta.
\end{abstract} All rights reserved.

\section{Abstract}

The study aims to 1) describe the types of traditional games related to mathematical activities, 2) examine the role of traditional children's games in the practice of numeracy skills, and 3) examine the role of traditional children's games in introducing flat shape to children in Hamparan Perak Village. This study used a qualitative approach that the data obtained were analyzed descriptively. Research subjects as many as 40 people who are at elementary school age (SD) who is domiciled in Hamparan Perak Village. Data collection techniques are observation, interview, and documentation. The results of the research are: 1) traditional game type that contains the element of mathematics that is traditional game of kelleng, marbles, and rocks, 2) traditional games to train children to count, recognize numbers, and numeracy skills such as addition and multiplication, 3) traditional games making children will be lines, rectangles, rectangles, and triangles.

Copyright (C) 2018 Universitas Mercu Buana Yogyakarta. All rights reserved.

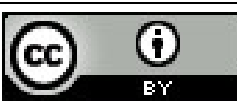

$\mathrm{W}:$ http://ejurnal.mercubuana-yogya.ac.id/index.php/mercumatika

E : mercumatika@mercubuana-yogya.ac.id 


\section{PENDAHULUAN}

Permainan tradisional adalah kegiatan yang bersifat menghibur yang menggunakan alat sederhana dan tanpa alat yang telah diwariskan dari generasi kegenerasi. Permainan tradisional memberikan manfaat yang baik untuk perkembangan anak baik fisik, emosi, dan kognitif anak. Hasanah \& Pratiwi (2017)_ menjelaskan bahwa melalui bermain, anak banyak mempelajari konsep dasar seperti mengenal warna, bentuk, arah, huruf, dan angka. Begitu juga halnya Iswinarti (Tim Playplus Indonesia, 2017) menyatakan bahwa alternatif pendidikan untuk mengoptimalkan perkembangan anak yaitu melalui menerapkan kembali permainan tradisional.

Dharmamulya \& dkk (2008) menyatakan perlu upaya pelestarian permainan tradisional, salah satunya dengan menunjukkan fungsi dari permainan tradisional anak dengan pewarisan nilainilai budaya. Oleh karena itu, peneliti ingin ikut berperan dalam pelestarian permainan tradisional anak, dengan cara mengkaji manfaat permainan tradisional dalam mengembangkan kemampuan matematika anak.

Kemampuan matematika anak usia SD meliputi kemampuan memahami konsep matematika, kemampuan berhitung dan kemampuan pemecahan masalah. Kemampuan tersebut diperoleh anak setelah mengikuti pembelajaran pada materi bilangan cacah dan operasi hitung, geometri dan pengukuran, dan pengolahan data. Hudojo (2005) menyatakan untuk mengajarkan keterampilan berhitung pada siswa SD, salah satunya dengan metode latihan.

Siswa SD kelas I, II, III, dan IV yang telah melaksanakan pembelajaran diharapkan sudah mahir dalam berhitung. Namun kenyataannya, berdasarkan yang disampaikan salah satu guru SDN 105277 Hamparan Perak yakni Pak Amri, ada 20 siswa SD yang belum dapat berhitung. Sebahagian dari 20 siswa tersebut, setiap harinya menghabiskan waktunya dengan bermain permainan elektonik seperti game online di warnet. Junariah (2015) menyatakan guru yang memberikan pembelajaran logika matematika yang tidak sesuai dengan anak pada tahapan usia suka bermain, mengakibatkan sebagian anak belum mengenal angka, mengenal konsep bilangan, dan belum mengenal bentuk-bentuk geometri.

Berdasarkan hal tersebut, untuk mengasah kemampuan anak dalam berhitung, anak membutuhkan kegiatan bermain dengan permainan tradisional. Ulya (2017) menyatakan bahwa melalui permainan tradisional siswa memperoleh pengalaman langsung dalam situasi nyata dalam mempelajari konsep matematika.

Berbagai penelitian menunjukkan bahwa permainan tradisional memberikan manfaat dalam mengembangkan kemampuan matematika anak. Junariah (2015) menyatakan bahwa peran yang diberikan permainan tradisional dalam pengembangan kecerdasan jamak logika matematika anak usia 4-5 tahun sebesar 47\%. Damayanti \& Putranti (2016) menyatakan bahwa menggunakan permainan engklek dapat meningkatkan hasil belajar siswa sebesar $69 \%$. Kedua penelitian tersebut dilakukan dalam lingkup sekolah.

Kemampuan anak usia SD di bidang matematika, tidak hanya diperoleh anak melalui pendidikan formal atau dalam atmosfer kelas, tetapi juga di lingkungan rumah. Oleh karena itu, penelitian ini melihat anak usia SD bermain permainan tradisional di lingkungan rumah. Adapun tujuan penelitian ini untuk: 1) mendeskripsikan jenis-jenis permainan tradisional yang berkaitan dengan matematika, 2) menelaah peranan permainan tradisional anak dalam melatih kemampuan berhitung anak dan, 3) menelaah peranan permainan tradisional anak dalam mengenalkan bentuk bangun datar pada anak usia sekolah dasar di Desa Hamparan Perak.

\section{METODE}

Penelitian ini menggunakan pendekatan kualitatif. Penelitian ini dilaksanakan di Desa Hamparan Perak dengan masa dimulai dari bulan April s.d. Agustus 2017. Subjek penelitian adalah anak-anak usia sekolah dasar (6-12 tahun) sebanyak 40 orang. Dalam memperoleh data yang dibutuhkan, peneliti berbaur dengan subjek, observasi, wawancara, dan dokumentasi. Data yang diperoleh dianalisis dengan metode berfikir ilmiah yaitu mendeskripsikan, menghubungkan, dan membandingkan temuan di lapangan. 


\section{HASIL DAN PEMBAHASAN}

Jenis-jenis permainan tradisional yang diperoleh pada penelitian di desa Hamparan Perak antara lain: kuda lumping, batu serimbang, engklek, rumahan dari tanah, engklek, masak-masakan, tulup, kelereng, gasing, alep jongkok, alep perancis, dan keretaan dari pelepah kelapa. Jenis-jenis permainan tradisional anak yang berkaitan dengan matematika antara lain : engklek, batu serimbang, kelereng.

a. Engklek

Ada 3 bentuk engklek yang dimainkan anak di Desa Hamparan Perak, yaitu : engklek bentuk pesawat, engklek bentuk lemari, dan engklek bentuk orang. Adapun pola atau bentuk engklek yang dimaksud seperti yang tampak pada gambar 1, gambar 2, dan gambar 3 berikut:

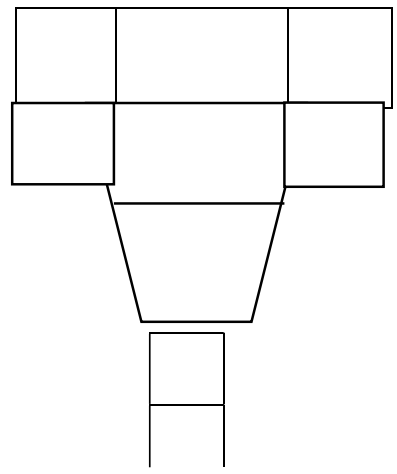

Gambar 1. Engklek pesawat

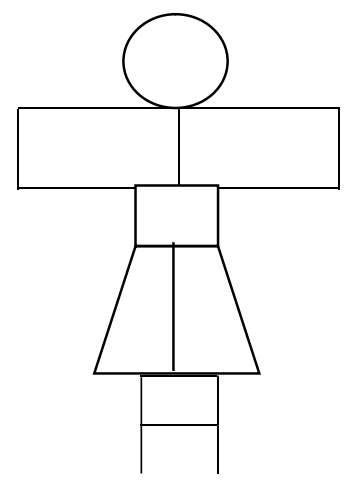

Gambar 2. Engklek orang

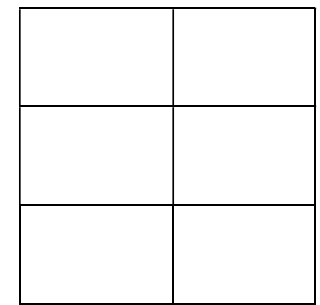

Gambar 3. Engklek lemari

Alat yang digunakan anak untuk membentuk pola engklek yaitu kayu atau batu merah di tanah lapang. Setiap pemain menggunakan satu gacok (benda yang berbentuk pipih) biasanya dari pecahan genting, keramik, batu, dan beling.

Permainan engklek secara umum, pemain harus melempar gacok ke satu kotak, selanjutnya menekuk satu kaki sambil melompati semua kotak dari pola engklek. Aturan permainan engklek yaitu bila gacok itu dilempar tetapi gacoknya berada di luar kotak yang dimaksud, maka pemain itu 
Vol. 2, No. 2, April 2018, pp. 1-7

berhenti sementara dan apabila pemain menginjak garis, maka pemain tersebut mesti berhenti bermain. Berikut alur permainan engklek di Desa Hamparan Perak:

- Menentukan yang bermain pertama dan seterusnya secara terurut, dilakukan dengan hompimpa.

- Permainan dimulai dengan melempar gacok ke dalam satu kotak engklek.

- Pemain melompati kotak dalam pola engklek dengan menekuk satu kaki.

- Kotak yang ada gacok, tidak dapat diinjak oleh pemain.

- Pemain yang berhasil melempar gacok ke kotak dan berhasil melalui semua kotak, kemudian membungkuk untuk mengambil gacok lalu melompat keluar kotak.

- Pemain yang telah berhasil melempar gacok pada semua kotak, maka tugas pemain berikutnya adalah memperoleh "rumah". Caranya, pemain harus membelakangi kotak engklek dan melemparkan gacok melewati kepalanya yang mengarah pada salah satu kotak engklek. Jika berhasil, maka pemain dapat membuat tanda rumah pada kotak yang berhasil dimasuki gacok.

- Pemain yang memperoleh tanda rumah pada kotak engklek, boleh menginjak kotak tersebut dengan kedua kakinya.

- Akhir permainan yaitu jika semua kotak engklek telah diberi tanda rumah. Pemain yang memiliki paling banyak tanda rumah pada kotak engklek dinyatakan sebagai pemenangnya.

b. Batu serimbang

Permainan batu serimbang dimainkan anak-anak perempuan sebanyak 2 sampai 3 orang. Permainan ini menggunakan 5 butir batu kerikil. Penentuan yang bermain pertama dengan melakukan hompimpa atau suiten. Cara bermainnya dengan menyebarkan batu kerikil, selanjutnya mengkaut kerikil, mulai dari kaut 1 butir, 2 butir, 3 butir dan seterusnya. Jika ada batu yang tidak terkaut atau mengkaut suatu butir mengenai butir lain, maka permainan anak tersebut dihentikan sementara dan dilanjutkan dengan pemain berikutnya. Dalam permainan ini, anak berusaha untuk mengumpulkan butir sebanyak 50 butir. Anak yang terlebih dahulu mengumpulkan 50 butir itu menjadi pemenangnya.

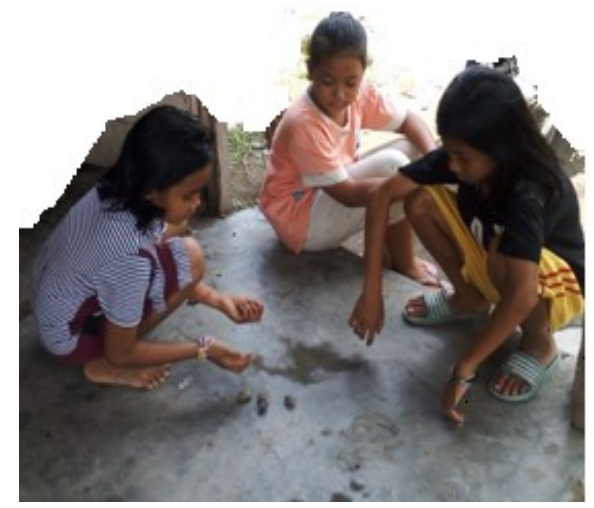

Gambar 4. Anak-anak bermain batu serimbang

\section{c. Kelereng}

Permainan kelereng dimainkan oleh anak laki-laki sebanyak 2 (dua) orang atau lebih. Pemain membuat garis (batas) jarak pemain untuk membidik kelereng yang dituju. Pemain melukis tanah sehingga berbentuk persegi atau segitiga sebagai tempat kelereng yang akan dibidik. Setiap pemain mengeluarkan kelereng dengan sama banyak, untuk ditempatkan dalam persegi atau segitiga tersebut. Pemain berusaha mengeluarkan kelereng dari persegi atau segitiga tersebut. Pemain yang berhasil mengeluarkan kelereng dari persegi tersebut, mendapatkan peluang untuk mematikan kelereng pemain yang lain, dengan cara mengenai kelereng pemain lain. Pemain yang berhasil mematikan semua pemain lain, memenangkan semua kelereng yang ada dalam persegi atau segitiga tersebut. 


\section{Kegiatan Berhitung dalam Permainan Tradisional Anak}

Permainan tradisional anak yang di dalamnya ada kegiatan berhitung antara lain permainan engklek, kelereng, dan batu serimbang. Kegiatan berhitung yang dimaksud yaitu konsep bilangan termasuk membilang, pengenalan angka, membandingkan (lebih banyak dan lebih sedikit), dan melakukan penjumlahan serta perkalian.

Kegiatan berhitung pada permainan engklek terjadi di akhir permainan engklek. Anak menghitung banyak rumah yang telah dilukis di setiap kotak engklek. Pemain engklek ada 5 orang, dengan pola engklek yang dimainkan berbentuk pesawat. Pemain A memperoleh 3 rumah, pemain B memperoleh 2 rumah, pemain $C$ memperoleh 4 rumah, pemain $D$ memperoleh 1 rumah, dan pemain $\mathrm{E}$ memperoleh 1 rumah. Pemain engklek membandingkan perolehan rumah dari setiap pemain. Pemenang permainan engklek adalah yang mendapatkan tanda rumah paling banyak. Pemain yang memperoleh paling banyak rumah yaitu pemain $\mathrm{C}$ sebanyak 4 rumah. Jadi pemenangnya adalah pemain $\mathrm{C}$.

Dalam permainan kelereng, setiap pemain meletakkan banyak butir kelereng yang disepakati ke dalam persegi. Anak-anak menyepakati banyak kelerengnya 2 butir, 3 butir, 4 butir, dan 5 butir. Banyak anak yang bermain ada 4 (empat) orang. Semua pemain sudah meletakkan banyak kelereng yang sudah disepakati kedalam persegi. Satu pemain menghitung banyak kelereng yang ada dalam persegi tersebut. Pemain yang menghitung tersebut bermaksud untuk mencek banyak kelereng. Caranya menghitung satu persatu kelereng yang ada di dalam persegi dan mengitung banyak pemain dengan kelereng yang diberikan. Banyak kelereng yang disepakati 3 butir jadi 4 × $3=12$, ternyata banyak kelereng yang ada di dalam persegi itu ada 12 butir, sehingga sipenghitung itu mengatakan pas (tepat banyaknya). Setelah pengecekan tersebut, permainan kelereng dimulai.

Permainan batu serimbang membutuhkan kemampuan berhitung. Ada 3 (tiga) anak yang sedang bermain batu serimbang. Anak melihat kerikil yang telah disebar dan mengkaut kerikil secara satu persatu. Anak tersebut melanjutkan permainan dengan mengkaut kerikil sebanyak 2 butir dari kerikil yang telah disebar. Anak tersebut berlanjut lagi dengan mengkaut kerikil sebanyak 3 butir dan mengkaut kerikil sebanyak 4 butir. Anak A pada ulang alek pertama memperoleh 3 butir, pada ulang alek kedua memperoleh 4 butir. Jadi anak A sudah memperoleh 7 butir. Anak A, $\mathrm{B}$, dan $\mathrm{C}$ bermain hingga salah satu dari mereka ada yang telah mengumpulkan 50 butir kerikil. Jadi anak melakukan penghitungan terlebih dahulu sebelum mengkaut kerikil yang telah disebar. Kegiatan berhitung dilanjutkan lagi dengan menghitung banyak kerikil yang diperoleh dari setiap ulang alek yang telah dilakukan.

\section{Menggambar Bangun Datar melalui Permainan Tradisional Anak}

Permainan tradisional yang di dalamnya, ada menggunakan bentuk bangun datar yaitu permainan engklek dan kelereng. Bangun datar yang dimaksud adalah persegi dan segitiga, sedangkan unsurnya adalah garis.

Pada permainan engklek anak membuat pola engklek dari berbagai bangun datar. Dalam membuat pola engklek bentuk pesawat, anak melukisnya dengan berbagai bangun datar seperti persegi, persegi panjang, dan trapesium. Membuat pola engklek bentuk orang, anak melukisnya dengan berbagai bangun datar seperti persegi, persegi panjang, dan lingkaran. Engklek bentuk lemari, anak membuat polanya dari rangkaian persegi panjang.

Pada permainan kelereng, anak memakai kata garis dan membuat garis sebagai pembatas jarak pembidik dengan kelereng yang akan dibidik. Disamping itu, nama dan bentuk bangun datar disebutkan anak ketika memainkan permainan kelereng. Anak juga melukis segitiga atau persegi di tanah sebagai wadah untuk meletakkan kelereng yang akan dibidik anak.

Jenis-jenis permainan tradisional anak yang kegiatannya berkaitan dengan matematika, di desa Hamparan Perak di antaranya permainan tradisional engklek, kelereng dan batu serimbang. Matematika yang dimaksud pada permainan tradisional engklek, kelereng, dan batu serimbang adalah matematika yang dipelajari oleh anak siswa Sekolah Dasar (SD) kelas rendah yaitu kelas I, II, III. Hasanah \& Pratiwi (2017) menjelaskan bahwa permainan tradisional bermanfaat untuk mengenalkan konsep dasar seperti angka. 
Vol. 2, No. 2, April 2018, pp. 1-7

Dalam permainan tradisional, anak melakukan kegiatan berhitung. Permainan engklek yang dimainkan anak, pada akhir permainannya, anak menyebutkan banyak rumah yang diperoleh setiap pemain dan membandingkan (lebih banyak atau lebih sedikit). Kegiatan membandingkan tersebut membuat anak dapat menyimpulkan pemain yang menang. Pada permainan kelereng, anak menghitung banyak kelereng yang akan diletakkan ke dalam persegi atau segitiga dan menghitung banyak kelereng yang sudah ada dalam persegi atau segitiga. Pada permainan batu serimbang, anak menghitung terlebih dahulu sebelum mengkaut kerikil tersebut. Anak menghitung dari setiap perolehan kerikil dari ulang alik yang dilakukan. Anak melakukan penghitungan sampai berjumlah 50 butir. Dapat dinyatakan bahwa permainan tradisional anak memiliki peran dalam melatih anak untuk berhitung.

Dharmamulya dkk (2008) menjelaskan bahwa permainan tradisional anak-anak di Jawa mempunyai fungsi melatih kecakapan berfikir dan melatih kecakapan berhitung. Sejalan dengan hasil Araujo dkk (2013) yaitu permainan tradisional seperti pathilan, dakon, nekeran, kubuk manuk, pasaran, bundaran, dan sebagainya dapat meningkatkan kemampuan berhitung pada anak. Begitu juga dengan penelitian Junariah, bahwa $47 \%$ permainan tradisional mempunyai hubungan dalam mengembangkan kecerdasan logika matematika anak.

Permainan engklek di daerah Banjar disebut bajujunggatan. Hasanah \& Pratiwi (2017) menjelaskan bahwa permainan bajujunggatan membantu perkembangan kognitif anak, mengenal konsep bilangan, dan membantu anak mengingat nomor dari setiap kotak. Adapun pola engklek yang diungkapkan oleh Hasanah dan Hardiyanti tersebut seperti gambar 5 berikut:

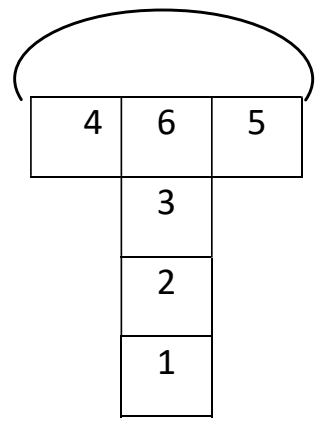

Gambar 5. Engklek huruf T

Dalam permainan tradisional, anak juga melakukan kegiatan seperti di sekolah yaitu membuat garis, persegi, persegi panjang, trapesium, segitiga, dan lingkaran. Pada permainan engklek, anak membuat persegi, persegi panjang, trapesium, dan lingkaran. Pada permainan kelereng anak membuat garis, persegi, dan segitiga. Sejalan dengan hasil penelitian Damayanti \& Putranti (2016) yaitu permainan tradisional engklek dapat dimanfaatkan untuk mempelajari konsep luas bangun datar persegi, persegi panjang, dan trapesium.

\section{SIMPULAN}

Berdasarkan hasil penelitian dan pembahasan yang telah diuraikan sebelumnya, dapat ditarik kesimpulan bahwa jenis-jenis permainan tradisional yang berkaitan dengan matematika yaitu permainan tradisional engklek, batu serimbang, dan kelereng. Permainan tradisional melatih anak usia Sekolah Dasar di Desa Hamparan Perak untuk membilang, membandingkan, dan kegiatan berhitung seperti menjumlah dan mengalikan. Permainan tradisional membuat anak usia sekolah dasar untuk menggambar garis, persegi, persegi panjang, trapesium, segitiga, dan lingkaran. 


\section{DAFTAR PUSTAKA}

Araujo, \& dkk. (2013). Peningkatan Kemampuan Belajar Hitung Pada Anak Melalui Ragam Permainan Kreatif. Prosiding Elektronik PIMNAS, 1-9.

Damayanti, A. D. ., \& Putranti, R. . (2016). Pembelajaran Matematika dalam Permainan Tradisional Engklek Untuk Siswa SD Kelas V. Prosiding Seminar Nasional Matematika dan Terapannya Universitas Jenderal Soedirman, 253-260.

Dharmamulya, S., \& dkk. (2008). Permainan Tradisional Jawa. Yogyakarta: Kepel Press.

Hasanah, N. I., \& Pratiwi, H. (2017). Pengembangan Anak Melalui Permainan Tradisional. Yogyakarta: Aswaja Pressindo.

Hudojo, H. (2005). Pengembangan Kurikulum dan Pembelajaran Matematika. Malang: Universitas Negeri Malang.

Junariah. (2015). Hubungan Permainan Tradisional Dengan Pengembangan Kecerdasan Jamak Logika Matematika Anak Usia 4-5 tahun. Bandar Lampung: Universitas Lampung.

Tim Playplus Indonesia. (2017). Ensikolpedia Permainan Tradisional Anak Indonesia. Jakarta: Erlangga.

Ulya, H. (2017). Permainan Tradisional Sebagai Media Dalam Pembelajaran Matematika. Prosiding Seminar Nasional Pendidikan Universitas Muhammadiyah Metro, 371: 376. 